\section{Ljupco Eftimov ${ }^{1}$}

Predrag Trpeski

Gjorgji Gockov $^{3}$

Ss. Cyril and Methodius University in Skopje,

Faculty of Economics-Skopje, Macedonia

Vesna Vasileva ${ }^{4}$

Imperial Tobacco TKS Skopje, Macedonia
ORIGINAL SCIENTIFIC ARTICLE doi:10.5937/ekonomika1602029E

Received: April 4, 2016

Accepted: May 9, 2016

\title{
DESIGNING A BALANCED SCORECARD AS STRATEGIC MANAGEMENT SYSTEM FOR HIGHER EDUCATION INSTITUTIONS: A CASE STUDY IN MACEDONIA
}

\begin{abstract}
European higher education institutions (HEIs) in the last two decades have faced a number of challenges: reduced public funding, increased competition from foreign and private universities, constant pressures and demands for their greater quality, and constant changes of education laws and legal regulations.

The only way for fast adjustment of HEIs to the new competitive conditions is to explore all possibilities for effective implementation of some of the most popular management concepts such as Balanced Scorecard (BSC) system.

Although the application of the BSC in the business sector is well documented, limited research has been reported regarding the application of the BSC in the education sector.

For this purpose, relied on the existing literature, reported results and experiences from its implementation in business, firstly, we propose a suitable process for building a BSC system for HEI, and then we design a specific Strategy map and BSC system applicable for the Faculty of Economics-Skopje, Ss. Cyril and Methodius University, easily adaptable for implementation in other HEIs.
\end{abstract}

Key words: higher education institutions, reforms, performance management, strategy maps, Balanced Scorecard.

JEL classification: I23, M10, M120, M190

\footnotetext{
${ }^{1}$ ljupco.eftimov@gmail.com, ljupco.eftimov@eccf.ukim.edu.mk

${ }^{2}$ predrag.trpeski@eccf.ukim.edu.mk

3 gjorgji.gockov@eccf.ukim.edu.mk

${ }^{4}$ vesna.vasileva@gmail.com 


\title{
ПРОЈЕКТОВАЊЕ БАЛАНСНЕ КАРТЕ КАО СИСТЕМА СТРАТЕГИЈСКОГ МЕНАЏМЕНТА: СТУДИЈА СЛУЧАЈА У МАКЕДОНИЈИ
}

\begin{abstract}
Апстракт
Европске институиије високог образовања се у последње две деценије суочавају са бројним изазовима: смањено јавнао финансирање, све већа конкуренција из иностранства и приватних универзитета, стални притисци и захтеви за већим квалитетом, и константне промене закона о образовағу и законских прописа.

Једини начин за брзо прилагођавање високошколских институција на нове конкурентске услове је да се истраже све могућности за ефикасно спровођење неких од најпопуларнијих концепта управљања, као ито је систем балансне карте.

Иако је примена система балансне карте у пословном сектору добро документована, мали број истраживање је посвећен примени овог система у сектору образовања.

У ту сврху, базирано на постојећој литератури, забележеним резултатима и искуствима из његове примене у пословању, пре свега, предлажемо одговарајући процес за изградюу система балансне карте у високом образоваюу, а затим, дизајнирамо посебну стратегијску мапу и систем применьии на Економском факултету -Скопје, Универзитета Св. Кирил и Методије, лако прилагодљив за имплементацију у другим високошколским установама.
\end{abstract}

Кључне речи: високочколске установе, реформе, управљање перформансама, стратегијска мапа, балансна карта

\section{Introduction: The Importance of Higher Education in Europe through Facts}

The importance of the nine-centuries long higher education history in the development of today's modern Europe is definitely great and undeniable, as well as its image and influence around the world. Moreover, the first and the oldest university in the world is European - University of Bologna in Italy, which was founded in 1088.

Therefore, it should not come as a surprise, that Europe has always devoted its great attention to higher education on its territory. There are numerous reasons for that. Its potential to stimulate economic development, social cohesion and to improve the quality of life in society is huge. It has been estimated that each additional year of education above the population average, increases the productivity of an average EU country for $6.2 \%$ and a further $3.1 \%$ on a long run, mainly achieved through the contribution, which education has, over faster technical progress (de la Fuente and Jimeno 2005). Higher education enables achievement of higher income and higher employment rate. According to the results of scientific research conducted in $10 \mathrm{EU}$ countries, it can be 
firmly concluded that higher levels of education of the population (measured by the share of people with higher education than elementary education) reduces the rate of unemployment, among the less educated and those with higher education (Biagi and Lucifora, 2008). The impact that higher education has on a society is remarkable even in reducing the crime rate in a society and greater active involvement of educated people in social living (Woessmann, 2006). The Share project exposes a strong correlation between the level of education of population, i.e. their socio-economic status and their health. It is considered that $70 \%$ of the population with lower levels of education are physically inactive and even $50 \%$ of them are prone to being overweight compared to more educated population. This same applies to the mental health of the population. Individuals with lower income or less material resources, are mostly poorly educated people and often suffer from depression, especially in the north part of Europe. And according to a research done by Eurostat in 2010, systemic relationship between the level of education and mortality has been determined. It has been said that the expected lifespan is lower in the group of less educated population and it increases with the level of education (EC-DG ECFIN 2010, p.17).

Undoubtedly the higher level of education provides clearer image of the world and the way it functions, as well as a better understanding of our own role in a society. The new knowledge changes people, their habits, their values and their way of life. Ultimately, it changes individuals, society and the world for better. Therefore, any responsible society that tends to increase economic and social development and improve quality of life for its population, should always have the (higher) education in the primary focus of interest.

\section{The competitiveness of European higher education internationally}

Although Europe has always been known as the world university center and incubator of the global intelligence, still, it seems that the last few decades, European HEIs are failing to keep pace with the best HEIs in the Anglo-Saxon countries which seems to dominate in the educational market. For several years now, many different worldwide accepted university rankings, such as those of the Shanghai University or of the Times Higher Education, show that the top 20 HEIs in the world come from the Anglo-Saxon countries.

For example, in 2014, the top 20 ranked universities consisted barely four European universities, and three of them are British (University of Cambridge, University of Oxford and University College London) and one of them is Swiss (Swiss Federal Institute of Technology Zurich) (ARWU, 2014). Thus, global ranking in the top 50 bestranked universities includes only 7 universities of continental Europe (two from France, two from Germany, one from Switzerland, one from Denmark, and one from Sweden). There is not even one university from Italy, Austria, Belgium or Spain among them.

Similar results indicate also the annual ranking of the top 400 universities from the world ranking of Times Higher Education. In the academic year 2013/2014, again among the top 50 universities in the world, barely four, are from continental Europe (two from Switzerland, one from Netherlands, one from Germany). The rest are from United 
Kingdom, several from Canada, Australia, Japan and China, and the overwhelming majority belongs to US universities.

Despite the complete domination of the United States universities among the best HEIs in the world, the European education has also some advantages that should not be ignored. European HEIs have better average quality, are more accessible for students from lower social status families and focus more on long-term research. Also, some studies confirmed better results in Switzerland, Britain, Denmark, Spain, Sweden, Belgium, Canada and Australia, compared with the United States in terms of the number of published scientific papers per 10 researchers and one dollar invested (NOWT, 2003 in Jacobs and van deer Ploeg, 2006, p.538).

However, we should not neglect the fact that many of the best European students, researchers and teachers in search of a more thrilling life, higher salaries and more creative and dynamic work environment, migrate to the United States or Canada, that currently offers the best and the most competitive working conditions.

In order to reduce the brain drain, enhance the quality of higher education and recover the lost status of worldwide intelligence creator, over the last two decades, Europe undertakes various reforms. It was believed that through the consistent implementation of Bologna Declaration, Lisbon agenda, as well as its successor $\gg$ Europe 2020 «, that European HEIs will quickly manage to strengthen their role and build the most competitive society in the world, based on knowledge. But it is more than clear that those reforms were not enough.

\section{The Reforms in Higher Education in Europe}

During the late 1980s dissatisfaction of the continuous poor performances of the public institutions culminated worldwide. Inefficiency, bureaucracy, inflexibility towards changes and poor financial results represented their work. That was the trigger why governments in most countries started to implement the principles of market economy in the public sector. This transition from a market economy to a market society, also known as a trend of public sector commercialization did not avoid universities. Consequently, in many countries, governments started: (1) reducing the financial support for higher education (Hodson and Thomas, 2001); (2) requiring greater financial autonomy of educational institutions (Coy and Pratt, 1998); (3) encouraging competition by allowing free entrance to foreign and private universities (Tooley, 1998); and (4) imposing major reforms in higher education.

These changes and pressures undoubtedly created a need for greater responsibility and real managerial behavior at HEIs, far different from the past collegiate or confirmative management. The only way for rapid adjustments to the new conditions, was exploring the possibilities for effective implementation of popular management concepts and techniques in HEIs which were already proven in business. Hence, began the trend of testing and implementing of different management tools, such as Balanced Scorecard (Cardoso, Trigueiros and Narciso, 2005; Ruben, 1999; Stewart \& CarpenterHubin, 2000; Papenhausen \& Einstein, 2006, Umashankar \& Dutta, 2007; Karathanos \& Karathanos, 2005; Pineno, 2007; Cullen, Joyce, Hassall, \& Broadbent, 2003; Mashhadi, Mohajeri \& Nayeri, 2008), Benchmarking (Doerfel \& Ruben,2002), Data Envelope 
Analysis technique (Zheng \& Steward, 2002), EFQM excellence model (Osseo-Asare \& Longbottom, 2002; Calvo-Mora, Leal \& Roldan, 2006; Hides, Davies, Jackson, 2004; Tari 2006), Total Quality Management (Chadwick, 1995; Owlia \& Aspinwall, 1997) and others business tools. This trend corresponds with the generally accepted public sector policy towards the improvement of efficiency, effectiveness and financial performances in universities (Coy and Pratt, 1998; Tooley, 1998), as well as the Declaration of Graz which for successful reforms requires each educational institution to actively apply leadership, quality and strategic management (EUA Graz Declaration, 2003).

Nowadays, most universities operate in a competitive environment where all students are often treated as consumers or customers, education as a product and the operating area as an educational market (Craig, Clarke and Amernic 1999; Hodson and Thomas, 2001). We are witnessing a strong competitive struggle between HEIs for each student and the focus is moving from local to global educational market. Many of them, in order to promote students as customers of their services, started testing and measuring many indicators such as: student satisfaction rate, the number of enrolled/graduated students per year, the rate of rejected candidates, or proportion of full-time/part-time students, the number of signed agreements for cooperation with foreign universities or organizations, the number of published papers in the country and abroad, the proportion of computers/ students, and many others. But, many of these traditional measures do not reflect the real picture for the current status of the institution. They do not show the key factors for success of the faculty or university, nor take into account the most important dimensions of the organizational mission, vision and strategic goals (Doerfel and Ruben, 2002).

\section{From performance measurement to strategic management in HEIs by employment of BSC system}

In our opinion, the real answer to the management issues that HEIs are beginning to face: competitive market and »measurement of everything, but nothing that actually matters«, problems well known in the private sector, is the BSC system. Its creators Kaplan and Norton describe it as »a system that serves to translate the organizational mission and strategy into a modern set of measures that provides a basis for a strategic measurement and strategic management« (Kaplan and Norton, 1996). This is a simple, logical, practical and already proven management system and an appropriate response to the challenges faced by modern HEIs.

Our opinion is shared by many other authors. They point out that the BSC concept also allows: planning of the strategy and its cascading to all units of the educational institution, identifying the necessary steps for its implementation, as well as a successful selection of indicators that will ensure higher quality of education (Cardoso, Trigueiros and Narciso, 2005). And authors Ruben (1999), then Stewart and Carpenter-Hubin (2000), alike Papenhausen Einstein (2006), and Umashankar and Dutta (2007) explain in detail how BSC system can be successfully implemented in university education as a framework for quality management and organizational performance. Authors Karathanos and Karathanos (2005), however, indicate the importance of a clear relationship between measures with mission, core values and strategic goals of every organization. Pineno 
(2007) points BSC concept as a powerful tool for development and implementation of a strategic management system used for monitoring organizational performances in business schools. And Cullen, Joyce, Hassall, and Broadbent (2003) propose implementation of BSC concept in HEIs in order to strengthen their management capacity.

However, although in the past decade many universities worldwide successfully implemented the BSC concept in their work, only a few published papers and empirical studies explaining their specific experiences in the process of its implementation. But what should be pointed, is the fact that almost all registered results or to date experiences of HEIs that have experimented with BSC are positive and successful.

Thus, Hafner (1998) reported successful results from the application of the BSC concept in the University of California. Chang and Chow (1999) reported that in their study of 69 accounting department managers, the most of the examinees declared positively for the applicability and benefits of the BSC concept in the accounting educational programs. Armitage and Scholey (2004) successfully implemented the BSC concept of post-graduate studies in business, entrepreneurship and technology. Karathanos and Karathanos (2005) in details present the BSC systems that they applied in three USA universities. That makes them the first winners of the Malcolm Baldrige National Quality Award in the field of education. Yek, Penney and Seow (2007) argue the positive experiences from the application of the BSC concept in professional vocational education, or more specifically at the Institute of Technical Education of Singapore and also won the National Quality Award. Suraya, Yu, Soo and Mohamad (2008) achieved positive effects from the application of automatic or e-BSC system for performance measuring and success at the University of Malaysia.

\section{A brief view of the current situation in higher education in Macedonia}

Today, the higher education in Republic of Macedonia is treated as a public good. The Macedonian higher education from a privilege of a few, became everyone's right. Macedonian higher education suffered serious expansion in the last decade. The number of students has increased dramatically from 40.246 students in 2000/2001 to 56.687 students in 2013/2014. Greater number of students was accompanied by even greater increase in the number of universities - from a few public universities in 2000/2001 to 23 universities in 2015 ( 5 state universities and 18 private universities), or from 31 HEIs in 2000/2001 to 125 HEIs in 2013/2014 (State Statistical Office, 2015). As result of this expansion the educational attainment indicator in Macedonia (defined as the percentage of the population aged 30-34 who have successfully completed tertiary studies) has increased from $11.6 \%$ in 2006 to $28.5 \%$ in 2015 (Eurostat, 2016). Unfortunately, funds allocated from the budget for education and research did not follow the growing needs of education. The public expenditure for education has been reduced from $3.7 \%$ of GDP in 2004 to $3.5 \%$ of GDP in 2010, and the public expenditure for research and development has been reduced from $0.2 \%$ of GDP in 2003, to $0.1 \%$ of GDP in 2010 . This was followed also by a serious reduction in the amount of student tuition fees, from average 1.000 eur per academic year in 1998/99, to average 200eur per academic year in 
2014/2015. Meanwhile the Law on higher education, which was adopted in 2008, was subject to more than 20 amendments to date. We can conclude, that the Macedonian HEIs face the same challenges as their colleagues from the rest of Europe: increased number of students, reduced financial support from the government; reduced financial and other autonomy of educational institutions; severe competition from foreign and private universities; major legal reforms in higher education, changed focus of the academics from teaching to researching, need for more managerial skills and strategic focus.

The evident lack of strategic focus of the HEIs management is even confirmed in the National program for education development in Macedonia 2005-2015 by the Ministry of Education in Republic of Macedonia: »Strategic management and planning of institutional development should be critical in future reforms of higher education. Owing to the fact that at the moment they are not in the center of reforms, intensive training of the management structures at universities / faculties / institutes would be essential. The lack of appropriate knowledge and skills has already been identified from various international partners (World Bank, European Commission, UNESKO-CEPES)" (MON, 2006, p.308).

Having in mind these conditions and challenges, an employment of a BSC system for strategic management of universities in R. Macedonia is definitely highly recommended. The benefits from its application are not limited only on the improvement of the efficiency, effectiveness and financial responsibility of the HEIs, but also improvement of the quality of their services.

Education quality is a complex and elusive concept especially when we should prove it or measure it. But it is easily noticed by its absence. In the next several years each modern university will have to have a system that ensures its quality. University stakeholders, especially government and students will be more sensitive to quality issues. Those HEIs, which will succeed and offer high quality education, genuine and contemporary curriculum for its students, can attract better students. Nowadays, the best students can choose globally, between large number of studies. Therefore, HEIs should constantly identify and strengthen their competitive factors. Definitely, one of those factors that can significantly assist in providing continuous improvement and quality in the work of HEIs, is the implementations of management system for organizational performances in higher education (Cardoso and Trigueiros, 2007, p.4). Each Macedonian higher education institution should strive, with all its potentials, to constantly adjust and improve, correct its weaknesses, avoid external treats, and maximally exploit its strengths and opportunities offered in the environment.

Therefore our primary goal is, relying on the existing literature, reported results and experiences from its implementation in business, to propose a suitable process for building a BSC system for HEI and then to design a specific Strategy map and BSC system applicable for the Faculty of Economics-Skopje, Ss. Cyril and Methodius University, easily adaptable for implementation in other HEIs.

This also would be our modest contribution in filling the research gaps on the application of these management tools in developing countries pointed from different authors such as Samuels and Oliga (1982) and Wallace (1990), especially in the education institutions in developing countries (Lawrence and Sharma, 2002). 


\section{Proposing a specific process for designing a BSC system applicable in Macedonian HEIs}

Various authors in this area suggest many processes with different number of phases for designing and implementing the BSC system. However, most of them use similar sequence of phases or activities that consist this process. As a result of analyzing numerous practical and theoretical processes, we suggest specific process of creating the Balanced Scorecard system applicable in Macedonian HEIs (see Fig. 1). Phases are divided into two groups: phases of designing the BSC system and phases of implementing the BSC system.

Figure 1: Process of designing the BSC system for Macedonian HEIs

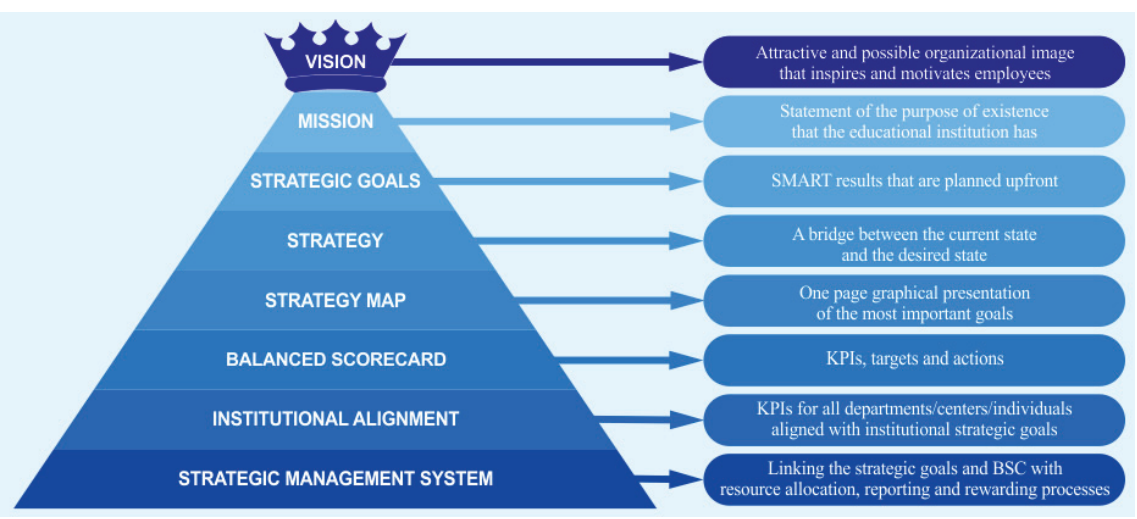

\section{Designing the Balanced Scorecard system}

The first phase of designing the BSC system process begins with defining the vision of the HEI. The vision represents an attractive and possible image that inspires and motivates the employees. The vision shows clear image for the institutional future. Creating a new vision, or redefining the existing, follows SWOT analysis, which helps identifying all the relevant opportunities and threats that can be found in external environment, as well as determining the internal strengths and weaknesses that the institution has.

The second phase of designing the BSC system process is specifying the institution's vision by defining its mission. Mission explains the purpose of existence that the educational institution has. The mission should provide "framework or context in which the strategies of the institution should be created" (Hill and Jones, 2008, p.11). Well defined mission defines the basic and unique intention of the institution, which is different from other HEIs and it determines range of activities from aspect of the educational programs and services that will be offered, as well as the students that will be targeted. It promotes a sense of expectation among the main stakeholders.

Quite interesting way of defining and understanding these two terms is the statement of the two management gurus - Warren Bennis and Bert Manus: "To choose a direction, a leader must first have developed a mental image of a possible and desirable 
future state for the organization. This image, which we call a vision, may be as vague as a dream or as precise as a goal or a mission statement. The critical point is that a vision articulates a view of a realistic, credible, attractive future for the organization, a condition that is better in some important ways than what now exists" (Bennis and Nanus, 1985, p.5).

The third phase of designing the BSC system process is translating the mission into strategic goals. Operationalization of the HEI mission can be seen as determining strategic goals for each department. The goals are future state, situation or desired result that is planned upfront. The goals should be SMART (specific, measurable, attainable, realistic and time-bound).

The forth phase of designing the BSC system process is forming the strategy for achieving these goals. After the strategic goals are being defined, the management of the institution should make a decision regarding the strategy or their implementation. The strategy is a bridge between the current state of the institution and the desired state. It should show us how to win a competition, how to best use the resources and the competitive advantages (Armstrong, 2003, p.104).

The fifth phase of designing the BSC system process is creating a strategy map. The strategy map is graphical presentation of the most important institutional goals. It is a logical structure of the organizational strategy which is created by presenting the relations between stakeholders, internal processes and abilities. In order a strategic map to be developed, the management should choose few strategic goals for each of the 4 perspectives that consist the BSC system, define their interaction and determine the causality in between. The strategy map provides a one page precise view of the organizational strategy, each perspective goals for their integration and connection in execution of the strategy. Strategic mapping should provide better communication in the institution, improved understanding and awareness of the employees for the strategy, as well as better execution of the strategy.

The sixth and last phase of this process, is the designing of the BSC system itself. It includes defining the most important strategic actions towards achieving the strategic goals, defining the key performance indicators (KPIs) that derive from the strategic goals and provide measurement of their achievement, as well as determining targets or standards for comparing each measurement shown in the Balanced Scorecard system.

With this phase, the designing process is finished and the process of implementing the Balanced Scorecard system begins.

\section{Implementing the Balanced Scorecard system}

The seventh phase that represents the beginning of the implementation process is the institutional alignment phase. In this phase, the designed BSC system is reviewed and approved by the management and then it is proceeded to operationalization. First, it should be automatized by connecting it to a software that will keep a track on the achievements of the goals and will alarm on time if there are significant deviations from the targets. Afterwards, the institutional BSC system is cascaded into additional complementary BSC systems for each department or center translating the HEI mission 
and goals into departmental actions, targets and KPIs. Moreover, these BSC systems can be further cascaded i.e. to translate to an individual level and this way to align day-to-day activities of the employees with the strategy and mission of institution.

The eight phase from the BSC system implementation process is the phase of finalizing the strategic management system. This phase starts with linking the strategic goals and BSC system with the resource allocation, reporting and rewarding processes. Without financial support for the core activities of the institution, results cannot be expected. Beside resource allocation, if you want to be sure that the job will be done you should measure it and reward it. Of course, one of the greatest benefits that the automatized $\mathrm{BSC}$ system has is the reporting - turning the results into valuable information for decision making and correcting the efforts towards achieving the goals or reviewing the goals. Connecting these three activities with BSC system, makes it not only a useful managerial tool for keeping track and controlling the operations in the institution, but a whole system for strategic management in the higher education institutions.

\section{Strategy map and BSC for Faculty of Economics-Skopje}

In addition we will approach the next phase of the process of designing a BSC system for Faculty of Economics-Skopje. With all due respect and discretion of the defined elements of the strategic plan of the faculty, we will take the right to perform their different and more appropriate grouping in the four perspectives of the BSC system, and provide them better and more efficiently alignment with the institutional mission in the Faculty Strategy Map (see Fig. 2). The strategic map is a graphical presentation of the most important goals of the faculty and their relation to cause-effect relationships.

Figure 2: Strategic map of Economics Faculty in Skopje
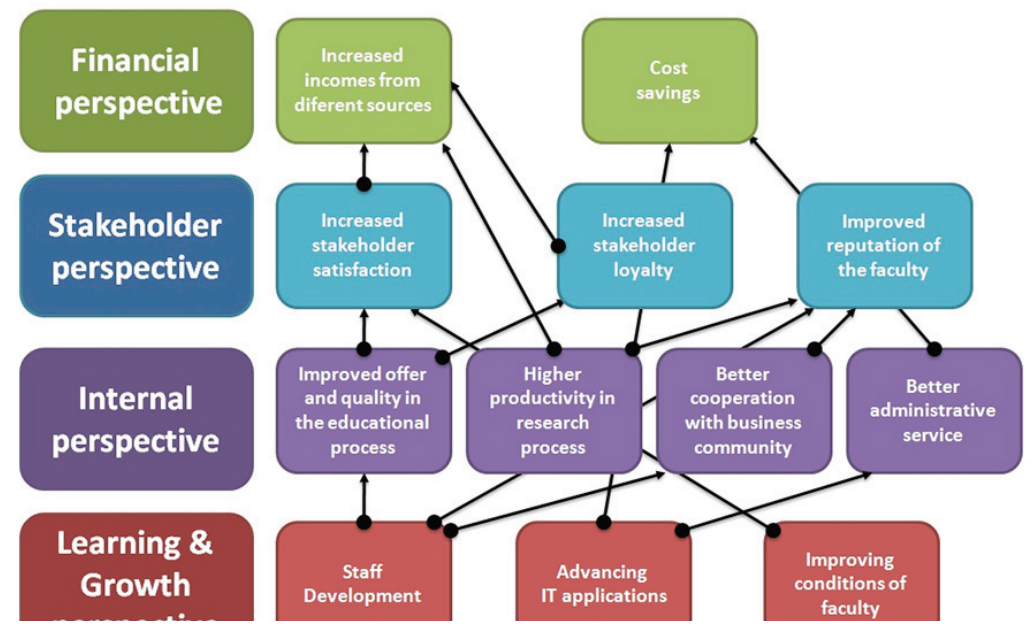

Development and improvement of knowledge, skills and abilities of employees will contribute to a better offer and quality in the educational process, higher productivity in the research process, and to better cooperation with the business community. Advancement and regular update of IT applications should contribute to improved 
student services and that, combined with the improvement of physical and technical conditions of the faculty, should result in an increased satisfaction rate of students and other stakeholders, their greater loyalty, and ultimately improved image of the faculty. These changes will certainly lead to increased and diversified income, as well as better utilization of resources and cost-effectiveness of the work of the faculty.

Below we continue with the four perspectives of the Faculty of Economics-Skopje BSC system.

\section{Learning \& growth- perspective}

In learning and growth- perspective, the strategic activities are classified into 4 groups: human capital, information capital, physical capital and organizational capital, whereas each of those groups of activities are defined objectives and key performance indicators for monitoring their achievement (see Fig. 3).

Figure 3: Learning and Development-perspective

\begin{tabular}{|c|c|c|}
\hline $\begin{array}{l}\text { Strategic } \\
\text { activity }\end{array}$ & Goal & Key performance indicators- KPIs \\
\hline 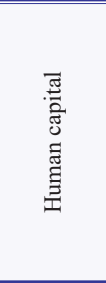 & $\begin{array}{l}\text { Development } \\
\text { and promotion of } \\
\text { knowledge, skills and } \\
\text { abilities of employees }\end{array}$ & $\begin{array}{l}\text { - } \\
\text { Number of employees promoted to higher academic- } \\
\text { scientific title } \\
\text { - } \\
\text { Number of study visits abroad } \\
\text { Number or hours spent on training courses, seminars for } \\
\text { enriching knowledge and didactic skills of employees } \\
\text { - } \quad \text { Gained awards and honorary titles } \\
\text { - } \quad \text { Funds provided from the budget for development of knowledge } \\
\text { and skills of employees }\end{array}$ \\
\hline 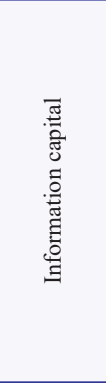 & $\begin{array}{l}\text { Improvement of } \\
\text { the information and } \\
\text { technical possibilities of } \\
\text { faculty }\end{array}$ & 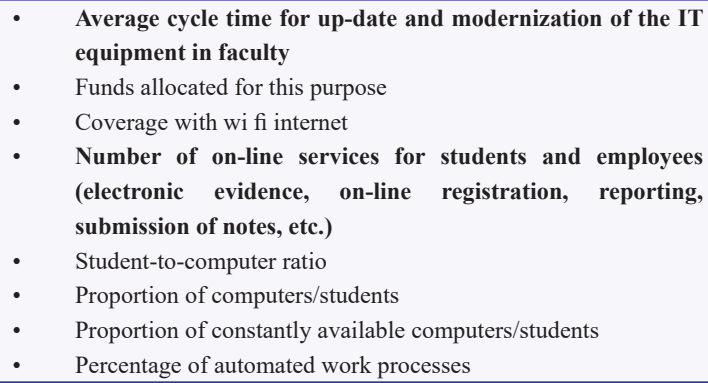 \\
\hline 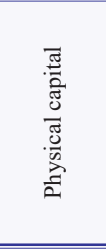 & $\begin{array}{l}\text { Improvement of the } \\
\text { spatial and technological } \\
\text { capabilities of faculty }\end{array}$ & $\begin{array}{l}\text { - Average cycle time of renewing and modernization of the } \\
\text { premises and teaching equipment } \\
\text { - } \quad \text { Funds allocated for improvement of conditions for study/work } \\
\text { - } \quad \text { Satisfaction rate of the students and employees } \\
\text { - } \quad \text { Degrable of utilization of the faculty's capacity (lecture halls, } \\
\text { classrooms, reading room, library, Internet center) }\end{array}$ \\
\hline 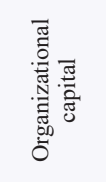 & $\begin{array}{l}\text { Promotion of the } \\
\text { organizational culture }\end{array}$ & $\begin{array}{ll}\text { - } & \text { Service oriented and entrepreneurial culture } \\
\text { - } & \text { Number of (realized) proposals for improving performance } \\
\text { - } & \text { Attitude toward change } \\
\text { - } & \text { Team spirit or group cohesion } \\
\text { Employee morale }\end{array}$ \\
\hline $\begin{array}{l}\text { Strategic } \\
\text { activity }\end{array}$ & Goal & Key performance indicators- KPIs \\
\hline
\end{tabular}




\section{Internal perspective}

In the internal perspective also the strategic activities are classified into 4 groups: teaching and educational process, research process, cooperation with business community and administrative process. For each of those groups of activities are defined two goals, and KPIs for monitoring their achievement (see Fig. 4).

Figure 4: Internal perspective

\begin{tabular}{|c|c|c|}
\hline $\begin{array}{l}\text { Strategic } \\
\text { activity } \\
\end{array}$ & Goal & Key performance indicators- KPIs \\
\hline \multirow[b]{2}{*}{ 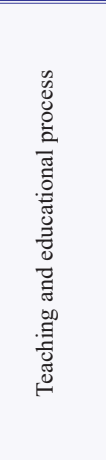 } & $\begin{array}{l}\text { Interactive and } \\
\text { modern teaching }\end{array}$ & $\begin{array}{l}\text { - Internal evaluation by the students } \\
\text { - Internal evaluation by the colleagues and employer } \\
\text { - External evaluation }\end{array}$ \\
\hline & $\begin{array}{l}\text { Innovation of the } \\
\text { curriculum }\end{array}$ & $\begin{array}{l}\text { - Number of new subjects } \\
\text { - Number of innovated existing subjects (over } \mathbf{2 5 \%}) \\
\text { - Number of new study programs }\left(1^{\text {st }} \text { or } \mathbf{2}^{\text {nd }} \text {-cycle) }\right. \\
\text { - Number of new professional and specialized programs and courses } \\
\text { - Number of joint degree programs with foreign universities in english language } \\
\text { - External evaluation for compliance of teaching plans and programs to the needs } \\
\text { of the economy and world's scientific achievements by accreditation bodies } \\
\text { or partner institutions from home and abroad }\end{array}$ \\
\hline \multirow{2}{*}{ 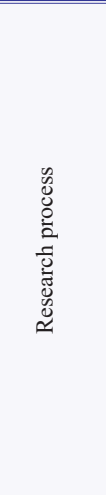 } & $\begin{array}{l}\text { Improving } \\
\text { productivity of the } \\
\text { academic staff }\end{array}$ & $\begin{array}{l}\text { - Number of published books, professional or scientific monographs in the } \\
\text { country and abroad } \\
\text { - Number of published scientific papers in peer-reviewed international and } \\
\text { domestic journals or conferences proceedings } \\
\text { - Number of organized international conferences } \\
\text { - Number of domestic and international professional and scientific journals, whic } \\
\text { hare regularly issued by the institution } \\
\text { - Number of applied research projects in the domestic or international institutions }\end{array}$ \\
\hline & $\begin{array}{l}\text { Increasing the impact } \\
\text { (meaning) of their } \\
\text { work }\end{array}$ & $\begin{array}{l}\text { - Proportion of submitted and accepted papers for presentation or publication } \\
\text { - Number of citations of the authors } \\
\text { - Ranking of journals by their Impact factor (industrial, academic impact) } \\
\text { - Memberships in national and international editing boards } \\
\text { - Domestic and international reviews } \\
\text { - Approved i.e. funded research projects }\end{array}$ \\
\hline \multirow{2}{*}{ 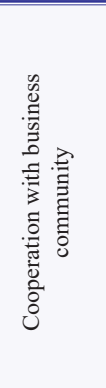 } & $\begin{array}{l}\text { Improvement of the } \\
\text { educational activity }\end{array}$ & $\begin{array}{l}\text { - Number of involved experts and professionals from certain areas of business } \\
\text { as guest lecturers } \\
\text { - Number of contracts with companies and institutions accepting students for } \\
\text { realization of practical teaching } \\
\text { - Number of representatives from the business community actively involved in } \\
\text { the creation and innovation of curriculum } \\
\end{array}$ \\
\hline & $\begin{array}{l}\text { Improvement of } \\
\text { the professional- } \\
\text { application activity }\end{array}$ & $\begin{array}{l}\text { - Number of conducted scientific and professional studies for the needs of } \\
\text { companies and institutions } \\
\text { - Number of realized innovations, inventions, patents and copyrights } \\
\text { - Number of realized proposals for cooperation with representatives from } \\
\text { business community as a result of Business Advisory Board of the faculty }\end{array}$ \\
\hline
\end{tabular}




\begin{tabular}{|c|c|c|}
\hline \multirow{2}{*}{ 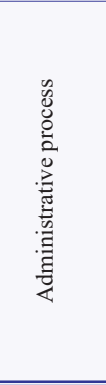 } & $\begin{array}{l}\text { Improving of } \\
\text { effectiveness of the } \\
\text { services }\end{array}$ & $\begin{array}{l}\text { - Student satisfaction rate } \\
\text { - Administrative cost per student } \\
\text { - Average time for registration of exams for certification of semesters for } \\
\text { response to students' requests, complaints, requests } \\
\text { - Number of complaints and appeals } \\
\text { - Efficiency in organizing exams and colloquiums } \\
\text { - Kindness and helpfulness of employees in the service }\end{array}$ \\
\hline & $\begin{array}{l}\text { Implementation of } \\
\text { ISO standards in } \\
\text { the operations of } \\
\text { administration }\end{array}$ & $\begin{array}{l}\text { - Respect of the procedures for movement, handling and storage of documents } \\
\text { - Respect of the imposed standards in operations }\end{array}$ \\
\hline $\begin{array}{l}\text { Strategic } \\
\text { activity } \\
\end{array}$ & Goal & Key performance indicators- KPIs \\
\hline
\end{tabular}

\section{Stakeholder perspective}

In stakeholder perspective, even though there are many, we focused on five groups of stakeholders, which in our view, are the most important, i.e. should be paid particular attention to: students, teachers and associates, alumni, government, Ministry of Education and Science, accreditation bodies and business community. For each of them are defined objectives and key performance indicators for monitoring their achievement (See Figure 5).

Figure 5: Stakeholder perspective

\begin{tabular}{|c|c|c|}
\hline $\begin{array}{l}\text { Strategic } \\
\text { activity }\end{array}$ & Goal & Key performance indicators- KPIs \\
\hline \multirow{4}{*}{ 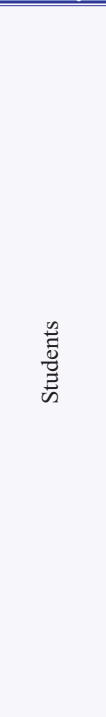 } & $\begin{array}{l}\text { Attracting the } \\
\text { best students }\end{array}$ & $\begin{array}{l}\text { - Number of applications/acceptances or rejections } \\
\text { - Average grades of secondary education and results from the state graduation of } \\
\text { the first year students } \\
\text { - Percentage of enrolled students from other countries } \\
\end{array}$ \\
\hline & $\begin{array}{l}\text { Improving the } \\
\text { efficiency of } \\
\text { studying }\end{array}$ & $\begin{array}{l}\text { - Retention metrics } \\
\text { - Percentage of students who have graduated and graduate on time } \\
\text { - Transition of the students in certain subjects }\end{array}$ \\
\hline & $\begin{array}{l}\text { Increasing } \\
\text { student } \\
\text { satisfaction of } \\
\text { various aspects } \\
\text { of studying }\end{array}$ & $\begin{array}{l}\text { - The students' satisfaction rate of the relevance and quality of the curriculum and content } \\
\text { - The students' satisfaction rate of teaching staff (skills and professionalism) } \\
\text { - The students' satisfaction rate of the administrative departments (library, reading } \\
\text { room, internet center, student center etc.). }\end{array}$ \\
\hline & $\begin{array}{l}\text { Improving } \\
\text { learning } \\
\text { outcomes, ie } \\
\text { studying }\end{array}$ & $\begin{array}{l}\text { - Increasing the employability of students for } \mathrm{X} \% \\
\text { - Average period to first employment of graduates } \\
\text { - Percentage of participation of the graduates in processes and programs for lifelong } \\
\text { learning } \\
\text { - Satisfaction rate and fulfillied expectations of graduates } \\
\text { - Employers' satisfaction rate with the performance and flexibility of students who } \\
\text { practice or work in their organisation. } \\
\text { - Interest of employers to participate in career fairs organized by faculty } \\
\text { - Programs for support or scholarships for students }\end{array}$ \\
\hline
\end{tabular}




\begin{tabular}{||l||l||l|l||}
\hline \hline & $\begin{array}{l}\text { Employees' satisfaction rate of working conditions (workspace, computer and } \\
\text { other equipment, free access to electronic database articles, rewarding) }\end{array}$ \\
- Proportion of teaching staff/number of students \\
- Even distribution of work duties \\
- Budget funds allocated for staff development \\
- Budget funds intended to support employees in research, publication and participation \\
in conferences
\end{tabular}

\section{Financial perspective}

Finally, follows the financial perspective in which the main focus is improving the financial management of the faculty operations by achieving two main objectives that will be monitored with these key performance indicators (see Fig. 6).

Figure 6: Financial perspective

\begin{tabular}{|c|c|c|}
\hline $\begin{array}{l}\text { Strategic } \\
\text { activity }\end{array}$ & Goal & Key performance indicators- KPIs \\
\hline \multirow{3}{*}{ 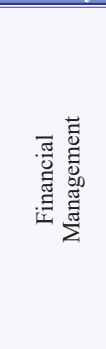 } & $\begin{array}{l}\text { Increase the revenues from various } \\
\text { sources }\end{array}$ & $\begin{array}{l}\text { Percentage of revenues from various sources (state funds, } \\
\text { student tution fees, research and consulting services, } \\
\text { donations and sponsorships, publishing, etc.). }\end{array}$ \\
\hline & \multirow[t]{2}{*}{$\begin{array}{l}\text { Better utilization and control of } \\
\text { resources }\end{array}$} & $\begin{array}{l}\text { Percentage of funds allocated for salaries } \\
\text { - Percentage of funds allocated for improvement of the working } \\
\text { conditions and studying } \\
\text { - Percentage of funds for research supporting } \\
\text { - Percentage of funds allocated for staff development }\end{array}$ \\
\hline & & $\begin{array}{l}- \text { Compliance of income and expenditure } \\
\text { - Average time of payment of the liabilities }\end{array}$ \\
\hline
\end{tabular}




\section{Discussion: Specific directions for implementing the BSC system in HEIs}

The offered list of approximately $100 \mathrm{key}$ performance indicators in the four perspectives of the Balanced Scorecard system, should be considered as preliminary. The list is not final nor necessarily appropriate for all the departments, centers or higher education institutions. A special attention, as pointed out before, should be devoted not to be caught in trap and follow all the indicators. The management should select only a limited number of the key performance indicators for each of the four perspectives which would best follow the strategic activities that aim towards achieving the strategic goals. It is advisable to choose 5-6 indicators for each perspective and maximum 8 indicators for the internal perspective. That would, practically, mean measuring and following not more than $\mathbf{3 0}$ key performance indicators. This way the management is unable "to measure everything that can be measured in an institution", which was one of the key critics of the traditional operating and measuring the organizational performance. The most appropriate KPIs for the Faculty of Economics-Skopje are those 30 KPIs which are marked with bold letters in the figures above. Connecting this limited number of indicators into a coherent system and their continuous measuring, can provide following to the organizational performances and determinate the level of organizational success on a pretty simple way. The management should and will be able to focus on the key factors that contribute to future success, instead of the indicators that show the results for some past activities and operations.

After defining the most important key indicators for the faculty operations, it is essential to set up targets or standards for each of the key performance indicators. That can be done by comparing the data and information that the faculty has from previous years (if those indicators were directly or indirectly followed) or by their forecasting. After the first year of implementation, the targets would be more precise for each KPI.

The core or generic BSC system developed for the faculty, does not have to be identical to the BSC system created for the department or centers. The concrete studies could have personal KPI that would be relevant to follow. The differences are more significant between the generic i.e. institutional BSC system and the individual BSC systems of the administrative offices. The last, measure the workflow and operating activities of the employees in the administrative offices compared to the educators. However, despite these differences, the individual and generic BSC systems should be aligned.

Measuring these performance indicators seems expensive and pretty complex process, however if a strong foundation has been set in the beginning, it could be relatively easy and cheap process. Most of the previously stated indicators can be followed using 3 or 4 types of questionnaires. The first type of questionnaire measures the student's satisfaction rate from the quality of the education (also known as process of self-evaluation of Macedonian higher education institutions). The second type of a questionnarie, again created on the same basis and merged with the first type of questionnarie, should measure the student's satisfaction rate from the quality of the administrative office services (student services, library, reading room, internet center, copy center, dormitories, student restaurant etc.). Both types of questionnaires would be electronic and mandatory for every 
student at the end of the semester, during students' verification of their semester. The student would not be able to apply online in the system for taking the exam or colloquium if he/she has not answered these questionnaires. The third type of a questionnaire should measure the faculty staff satisfaction rate (academic and administrative staff) from different working conditions. The forth type of a questionnaire is aimed at measuring the employers satisfaction rate by measuring the competences, knowledge, skills of the students' that do practical work, or are employed at their companies.

In order to provide more precise and real image of the institution's operation, despite these types of measurements, it is desirable to implement the methods of benchmarking and comparison to partner or other leading higher education institutions in that area, or to have direct grading from other peers for some aspects of the work operations (teaching programs, researches done, teaching methods, etc.). This way, the following of the progress would be more detailed.

\section{Conclusion: Expected advantages and benefits from implementing the Balanced Scorecard system to Faculty of Economics - Skopje}

According to the definition of Philpott \& Sheppard (1992): »The main purpose of the process of performance management is building a culture where every individual or group will take personal responsibility for the continuous improvement of internal processes, as well as their skills performance." (In Armstrong, 2004). The process of performance management using the BSC system is primarily responsible for the realization of organizational, team and individual performances. Simply, organizations need to do the right things in the right way.

The secondary objective of this process is constant development of employees. The continuous improvement of the results would not be possible if simultaneously there is no effective process of permanent development of employees' skills and abilities. Therefore, the process of managing the organizational performance many authors equate with the process of managing the organizational development.

Third, the performance management better meets the needs and expectations of all institutional stakeholders: students, professors and colleagues, administration, university managers, economy, government, accreditation bodies, taxpayers, donors and other interest groups. And last but not least, the performance management results in improved communication within the institution. It creates a climate for continuous dialogue between management and other members of the organization, aiming to clarify the expectations and organizational mission, goals and plans.

Perhaps one of the greatest benefits of the process of designing and implementing the BSC system in operation at the Faculty of Economics, as well as any other higher education institution, of course, despite the improved results of operations, is organizational cohesion and integrity among employees which is created through the process of communication and building consensus on the objectives and measurement indicators. Properly managed, this process focuses, motivates and informs employees about their achievements, with strengthening their sense of leadership. 
According to Pineno, the additional benefit from the implementation of such strategic performance management tool in one economic faculty, from a same rank as our faculty, is easier getting the AACSB International accreditation that requires continuous improvement of the quality and content of Management Education (2007). This is of particular importance for the Faculty of Economics in Skopje, which is in process of meeting the requirements for getting international accreditation. That would be a supplementary incentive for implementation of the BSC system in its operations.

Besides the expected improvement in the results of operations, the other additional benefits that can be expected from the successful implementation of BSC system in educational institution are: effective strategic management; organizational synergy; improved motivation and satisfaction of employees; effective communication in the organization; effective decision-making process; reduced costs; increased student satisfaction and satisfaction to other stakeholders; quick response to changes; increased competitive advantages.

\section{References}

Armitage, H., Scholey, C. (2004). Hands-On Scorecarding. CMA Management, 78 (6), pp. 34-38.

Armstrong, M. (2003). A Handbook of Human Resource Management Practice, 9th ed., London: Kogan Page.

ARWU, (2014). Academic Ranking of World Universities - 2014. Academic Ranking of World Universities, Retrieved 08.06.2015 from http://www.shanghairanking. com/ARWU2014.html

Bennis, W., Nanus, B., (1985), Leaders: The Strategies for Taking Charge, New York, US:Harper\&Row.

Biagi, F. and Lucifora, C. (2008). Demographic and education effects on unemployment in Europe. Labour Economics, 15 (5), pp.1076-1101

Calvo-Mora, A., Leal, A., Roldán, J. L. (2006). Using enablers of the EFQM model to manage institutions of higher education, Quality Assurance in Education, 14(2), 99-122.

Cardoso, E., Trigueiros, M.J. and Narciso, P. (2005). A Balanced Scorecard Approach for Strategy- and Quality-driven Universities. In: Proceedings of the 11th International Conference European University Information Systems EUNIS 2005.21-24 June. Manchester, UK: University of Manchester.

Cardoso, E., Trigueiros, M.J. (2007). Using The Balanced Scorecard As A Tool For Performance Management Of Higher Education. In: Proceedings of the 13th International Conference of European University Information Systems EUNIS 2007. 21-24 June. France: Grenoble Universities.

Chadwick, P. (1995). TQM at South Bank University: issues in teaching and learning, Quality Assurance in Education, 3(1), 39-44.

Chang, Otto H. and Chee W. Chow (1999). The Balanced Scorecard: a Potential Tool for Supporting Change and Continuous Improvement in Accounting Education. Issues in Accounting Education, 14 (3), pp.395-413. 
Charan, R., and Colvin, G., (1999), Why CEOs Fail, Fortune, June 21, 1999

Coy, D. and Pratt, M. (1998). An Insight into accountability and policies in universities: a case study. Accounting, Auditing and Accountability Journal, 11 (5), pp.540561.

Cullen, J., Joyce, J., Hassall, T. and Broadbent, M. (2003). Quality in higher education: From monitoring to management. Quality Assurance in Education, 11 (1), pp.5-14.

Craig, R.J; Clarke, F.LK and Amernic, J.H. (1999). Scholarship in university business Schools Cardinal Newman, Creeping Corporatisation and farewell to the "disturber of the peace"? Accounting, Auditing and Accountability Journal, 12 (5), pp.510- 524.

de la Fuente, A. and Jimeno, J. F. (2005). The Private and Fiscal Returns to Schooling and the Effect of Public Policies on Private Incentives to Invest in Education: A General Framework and Some Results for the EU, CESifo Working Paper, No. 1392

Doerfel, M. L. and Ruben, B. D. (2002). Benchmarking in higher education: Becoming more adaptive, innovative, and interactive organizations. In Bender B.E. and Schuh J.H, (eds.) Using benchmarking to inform practice in higher education (pp.3-25). San Francisco: Jossey-Bass.

Drtina, R., Gilbert, J.P. and Alon, I. (2007). Using the Balanced Scorecard for Value Congruence in an MBA Educational Setting. SAM Advanced Management Journal, 72 (1), pp.4-13.

EC, DG ECFIN (2010). Efficiency and Effectiveness of public expenditure on tertiary education in the EU, European Economy. Occasional Papers No. 70, European Commission - Directorate General for Economic and Financial Affairs. Retrieved on 08.06.2011, From http://ec.europa.eu/economy_finance/publications/ occasional_paper/2010/pdf/ocp70_en.pdf

EUA Graz Declaration (2003). Forward from Berlin: the Role of the Universities. Brussels: European University Association.

EUA Statement on the Bologna Process (2003). Berlin Ministerial meeting 18-19 September 2003. Brussels: European University Association. Retrieved on 08.06.2011, From http://www.eua.be/Libraries/CDE_website/EUA_Statement on_the_Bologna_Process-2003.sflb.ashx

Eurostat (2016), Tertiary educational attainment by sex, age group 30-34, Retrieved on 08.03.2016, From: http://ec.europa.eu/eurostat/tgm/table.do?tab=table\&init= $1 \&$ plugin $=1 \&$ language $=$ en \&pcode $=\mathrm{t} 2020 \_41$

Farid, D., Nejati, M. and Mirfakhredini, H. (2008). Balanced scorecard application in universities and higher education institutes: Implementation guide in an iranian context. Annals of University of Bucharest, Economic and Administrative Series, 2, pp.31-45.

Gündoğara, E., Hocalara, E., Taymazb, İ. and Çakırb, K. (2009). A Balanced Scorecard Based Performance Evaluation System: A Case Study At The Sakarya University. IABR and TLC Conference Proceedings, 16-19 March, 2009, San Antonio, Texas, US.

Hafner, K.A. (1998). Partnership for Performance: The Balanced Scorecard Put to the Test at the University of California. Retrieved on 08.06.2012, From http://www. ucop.edu/ucophome/businit/10-98-bal-scor-chapter.pdf 
Hides, M. T., Davies, J., Jackson, S. (2004). Implementation of EFQM excellence model self-assessment in the UK higher education sector - lessons learned from other sectors, The TQM Magazine, 16(3), 194-201.

Hill, Ch. and Jones, G. (2008). Strategic Management. New York: Houghton Mifflin Company.

Hodson, P.J. and Thomas, H.G. (2001). Higher Education as an International Commodity: Ensuring Quality in Partnerships. Assessment and Evaluation in Higher Education, 26 (2), pp.101- 112.

Kaplan, R.S. and Norton, D.P. (1996). Using the Balanced Scorecard as a Strategic Management System, Harvard Business Review, 74 (1), 75-85.

Karathanos D. and Karathanos P. (2005). Applying the Balanced Scorecard to Education. Journal of Education for Business, 80 (4), pp.222-230.

Kettunen, J. (2006). Strategies for the cooperation of educational institutions and companies in mechanical engineering, International Journal of Educational Management, 20(1), 19-28.

Lawrence, S. and Sharma, U. (2002). Commodification of Education and Academic Labour: Using The Balanced Scorecard in a University Setting. Critical Perspectives on Accounting, 13 (4), pp.661-677.

Mashhadi,M.M., Mohajeri, K. \& Nayeri,M.D. (2008), A Quality-Oriented Approach toward Strategic Positioning in Higher Education Institutions, World Academy of Science, Engineering and Technology, 37, pp.322-326

MON-Ministry of Education in the Republic of Macedonia (2006), National program for education development in Macedonia 2005-2015, Skopje, Macedonia: MON

NOWT (2003). Nederlandstalige Wetenschaps- en technologie-indicatoren 2003, CWS/MERIT, Maastricht. In: Jacobs, B. and van der Ploeg, F. (2006). How to Reform Higher Education In Europe, Economic Policy, July.

Osseo-Asare, A.E, Longbottom, D. (2002). The need for education and training in the use of the EFQM model for quality management in UK higher education institutions, Quality Assurance in Education, 10(1), 26-36.

Owlia, M. S., Aspinwall, E. M. (1997). TQM in higher education- a review, International Journal of Quality and Reliability Management, 14(5), 527-543.

Papenhausen, C. and Einstein, W. (2006). Insights from the Balanced Scorecard: Implementing the Balanced Scorecard at a College of Business. Emerald Group Publishing Limited, 10 (3), pp. 15-22.

Philpott, L. and Sheppard, L. (1992). Managing for improved performance, In M. Armstrong (2004). Strategies for Human Resource Management. 2nd ed. London, UK: Kogan Page.

Pineno, C.J. (2007). The Business School Strategy: Continuous Improvement by Implementing the Balanced Scorecard. Research in Higher Education Journal, 1, pp.68-77.

Ruben, B. (1999). Toward a balanced scorecard for higher education: rethinking the college and university excellence indicators framework. Higher Education Forum QCI Center for Organizational Development and Leadership, 99 (02), pp.1-10. 
Samuels, J. and Oliga J. (1982). Accounting Standards in Developing Countries. The International Journal of Accounting, 18 (1), pp.69-88.

Suraya Hamid, May Leen Yu, Hsaio Pei Soo, and Mohamad Taha Ijab (2008). Towards a Better Performance Measurement and Management in Assessing the Excellence of Academicians using the e-BSC. In: Proceedings fo Knowledge Management International Conference KMICe 2008, 10-12 June. pp. 293296. Langkawi: University Atara, Malaysia.

State Statistical Office of Republic of Macedonia (2015), Statistical Yearbook of the Republic of Macedonia-2015, State Statistical Office of Republic of Macedonia, Retrieved on 09.03.2016, From: http://www.stat.gov.mk/Publikacii/ PDFSG2015/06-Obrazovanie-Education.pdf

Stewart, A. and Carpenter-Hubin, J. (2000). The Balanced Scorecard: Beyond Reports and Rankings. Planning for Higher Education. 29 (2), pp.37-42.

Tar1, J. J. (2006). An EFQM model self-assessment exercise at a Spanish university, Journal of Educational Administration, 44 (2), 170-188.

Tooley, S. (1998). Structural and Administrative Reform of New Zealand's Education System: Its underlying theory and Implications for Accounting. Discussion Paper Series 185, pp.1-33. Massey: Massey University.

Umashankar, V., Dutta, K. (2007). Balanced scorecards in managing higher education institutions: an Indian perspective, International Journal of Educational Management, 21(1), 54-67.

Wallace, R. (1990). Accounting in developing countries: A review of the literature, Research in Third World Accounting, 1 (1), pp.1-22.

Yek, T. M., Penney, D. and Seow, A. C. H. (2007). Using Balanced Scorecard (BSC) to Improve Quality and Performance of Vocational Education and Training (VET): A Case Study in Singapore. Australian Association for Research in Education AARE 2007 Conference, November 25-29. Fremantle, Australia: Retrieved on 08.06.2012, From: http://www.aare.edu.au/07pap/yek07068.pdf

Zheng, H. Y., Stewart, A. A. (2002). Assessing the effectiveness of public research universities using NSF/NCES Data and Data Envelopment Analysis Technique. Air Professional File 83, Tallahassee, FL: Association for Institutional Reform 